\title{
ОПТИМІЗАЦІЯ УПРАВЛІННЯ РИЗИКАМИ НА ПІДПРИСМСТВІ НАФТОГАЗОВОЇ ПРОМИСЛОВОСТІ
}

Ю. М. Лях

Державна установа «Національний науково-дослідний інститут промислової безпеки та охорони праці» вул. Вавілових 13, м. Київ, 04060, Україна. E-mail: ndiop@ndiop.kiev.ua

Системи управління охороною праці на сучасному рівні їх розвитку все частіше використовують ризикоорієнтований підхід в процесі прийняття рішень, тому для підвищення безпеки виробництва запропоновано методичний підхід до оцінки ефективності заходів зі зниження рівня ризику виникнення аварій, випадків виробничого травматизму та професійної захворюваності на підприємствах нафтогазової галузі з урахуванням причинно-наслідкових зв'язків між реалізацією превентивних заходів та величиною ризику. Результати проведеного аналізу матеріалів розслідування нещасних випадків у нафтогазовій промисловості свідчать, що більшість заходів, спрямованих на запобігання травматизму на виробництві, полягає у проведенні позапланових інструктажів з питань охорони праці. На першому етапі вирішення задачі оптимізації управління ризиками проаналізовано стан виробничого травматизму у нафтогазовій промисловості за 2017-2018 р.р., причини його виникнення та основні статистичні показники. Проаналізовано події, в результаті яких були травмовані працюючі. Встановлено, що найчастіше нещасні випадки були пов'язані з невиконанням інструкцій з охорони праці, порушенням вимог безпечного виконання робіт, правил безпеки дорожнього руху, недооцінкою небезпеки, нехтуванням вимог безпечного виконання робіт підвищеної небезпеки. За результатами аналізу стану виробничого травматизму ідентифікації небезпек розроблена математична модель прогнозу величини ризику виникнення небезпечних ситуацій на об'єктах підприємства. Запропоновано алгоритм вибору оптимального плану превентивних заходів для зниження величини виникнення небезпечних ситуацій, основною відмінністю якого є використання математичної моделі прогнозу тенденцій зміни ризику, що дозволяє оцінити особливості впливу окремих заходів. Отримані результати дозволять підвищити ефективність планування заходів з охорони праці та безпеки виробництва. Запропонований підхід дозволяє перейти до наступного етапу - створення автоматизованої системи управління ОП на підприємствах нафтогазової промисловості.

Ключові слова: виробничий травматизм, професійні захворювання, ризик, прогнозна модель.

\section{ОПТИМИЗАЦИЯ УПРАВЛЕНИЯ РИСКАМИ НА ПРЕДПРИЯТИИ НЕФТЕГАЗОВОЙ ПРОМЫШЛЕННОСТИ}

\section{Ю. М. Лях}

Государственное учреждение «Национальный научно-исследовательский институт промышленной

безопасности и охраны труда»

ул. Вавиловых 13, м. Киев, 04060, Украина. E-mail: ndiop@ndiop.kiev.ua

Системы управления охраной труда на современном уровне их развития все чаще используют рискориентированный подход в процессе принятия решений.Поэтому для повышения безопасности производства предложен методический подход к оценке эффективности мероприятий по снижению уровня риска возникновения аварий, случаев производственного травматизма и профессиональной заболеваемости на предприятиях нефтегазовой отрасли с учетом причинно-следственных связей между реализацией превентивных мер и величине риска. Результаты проведенного анализа материалов расследования несчастных случаев в нефтегазовой промышленности свидетельствуют, что большинство мероприятий, направленных на предотвращение травматизма на производстве, заключается в проведении внеплановых инструктажей по вопросам охраны труда. На первом этапе решения задачи оптимизации управления рисками проанализировано состояние производственного травматизма в нефтегазовой промышленности за 2017-2018 г.г., причины его возникновения и основные статистические показатели. Приведен анализ событий, в результате которых были травмированы работающие. На основании проведенного анализа установлено, что чаще всего несчастные случаи были связаны с невыполнением инструкций по охране труда, нарушением требований безопасного выполнения работ, правил безопасности дорожного движения, недооценкой опасности, пренебрежением требований безопасного выполнения работ повышенной опасности. По результатам анализа состояния производственного травматизма и идентификации опасностей разработана математическая модель прогноза величины риска возникновения опасных ситуаций на объектах предприятия. Предложен алгоритм выбора оптимального плана превентивных мер для снижения величины возникновения опасных ситуаций, основным отличием которого является использование математической модели прогноза тенденций изменения риска, что позволяет оценить особенности влияния отдельных мер. Полученные результаты позволят повысить эффективность планирования мероприятий по охране труда и безопасности производства. Предложенный подход позволяет перейти к следующему этапу - создание автоматизированной системы управления охороною праці на предприятиях нефтегазовой промышленности.

Ключевые слова: производственный травматизм, профессиональные заболевания, риск, прогнозная модель.

АКТУАЛЬНІСТЬ РОБОТИ. За останні роки в Україні спостерігається зростання масштабів виробництва у нафтогазовій галузі, що спричинює зрос- тання наслідків від аварій, а також шкоди для здоров'я та життя працівників, насамперед тих, що виконують роботи з підвищеною небезпекою. 
Високий рівень травматизму у системі сучасного виробництва $\epsilon$ не тільки серйозною соціальною проблемою, пов'язаною 3 втратою працездатності, інколи і зі смертельним наслідком, а і має значний вплив на економічні показники діяльності підприємства.

Системи управління охороною праці на сучасному рівні їх розвитку все частіше використовують ризико-орієнтований підхід в процесі прийняття рішень $[1,2,3]$. На жаль, системи управління охороною праці для більшості підприємств України сформовані за реактивним принципом, який передбачає реагування на нещасні випадки та аварійні ситуації, а не за проактивним принципом, який базується на профілактиці. Такий стан справ ускладнює обгрунтований вибір пріоритетності профілактичних заходів з безпеки та гігієни праці на підприємствах [4].

Результати проведеного аналізу матеріалів розслідування нещасних випадків у нафтогазовій промисловості свідчать, що більшість заходів, спрямованих на запобігання травматизму на виробництві, полягає у проведенні позапланових інструктажів 3 питань охорони праці[1, 4].

Такий однотипний підхід до розв'язання проблеми без усунення причин настання нещасних випадків та аварій призводить до їх повторення [4, $5,6,7]$.

Тому виникає необхідність у створенні таких систем управління охороною праці, які б і дозволяли формувати економічно обгрунтовані заходи по підвищенню безпеки виробництва.

Основним критерієм оцінки ефективності управління безпекою праці в такій системі повинна бути фактична величина ризику, якому піддаються працівники на своїх робочих місцях, яку слід постійно порівнювати з нормативно визначеним допустимим рівнем ризику $[8,9]$.

Планування заходів повинно бути тісно пов'язано $з$ прогнозуванням стану охорони праці на підприємстві, що дозволяє: оцінити зміни стану безпеки виробництва у майбутньому; виявити показники i фактори, які найбільш істотно впливають на рівень небезпеки виробничих процесів, кількісно оцінити ступінь цього впливу; визначити можливі зміни в іiі структурі в майбутньому і спрогнозувати основні напрямки діяльності з підвищення безпеки виробництва; виявити альтернативні дії для досягнення поставленої мети, а також сформулювати саму мету; обгрунтувати управлінські рішення з оптимального розподілу наявних фінансових і матеріальних ресурсів; визначити пріоритетність вкладання коштів у профілактичні заходи [3].

Метою дослідження є підвищення ефективності управління охороною праці за рахунок використання методів математичного моделювання та оптимізації планування заходів зі зниження рівня ризику небезпечних ситуацій, виробничого травматизму і професійної захворюваності

МАТЕРІАЛ І РЕЗУЛЬТАТИ ДОСЛІДЖЕНЬ. Вивчення динаміки кількісних показників травматизму та професійної захворюваності дає можливість встановлювати закономірності їх зміни і з урахуванням цього прогнозувати ймовірні значення рівня ризику виробничого травматизму та аварій на виробництві [7].

Для ефективної профілактики виробничого травматизму вирішальне значення має визначення ймовірних причин нещасних випадків та вибір адекватних способів реагування на них шляхом запровадження відповідних заходів і засобів з охорони праці. Очевидна на перший погляд схема попередження виробничих травм при детальному аналізі переростає в одну з основних проблем безпеки праці - проблему визначення зв'язків між ризиками (загрозами, небезпеками) травмування та заходами, що можуть його зменшити або нейтралізувати повністю. Особливо актуальною стає ця проблема за необхідності виконання кількісних оцінок та прогнозів для планування заходів і засобів з охорони праці на майбутне.

Проаналізуємо стан виробничого травматизму у нафтогазовій промисловості за 2017-2018 роки. У 2018 році на підприємствах нафтогазової промисловості сталося 34 нещасні випадки (у 2017 році - 29), у тому числі 2 групові (у 2017 році - 4),травмовано 36 працівників (у 2017 році -35), у тому числі 3 із смертельним наслідком (у 2017 році -3). У 2018 році нещасні випадки сталися унаслідок таких подій:13 працівників (36 \% від загальної кількості потерпілих) травмовано унаслідок падіння потерпілого, 3 яких 1 із смертельним наслідком, у тому числі 6 у результаті падіння потерпілого під час пересування, 6 унаслідок падіння потерпілого з висоти, 9 у результаті дії предметів та деталей, що рухаються, розлітаються, обертаються, 3 у результаті падіння устаткування (обладнання) або їх конструктивних елементів, 3 унаслідок дорожньо-транспортних пригод на дорогах загального користування, 2 працівники постраждали у результаті дії шкідливих і токсичних речовин, смертельний наслідок в результаті ураження електричним струмом, один працівник помер у результаті погіршення стану здоров'я, один працівник постраждав унаслідок дії підвищених температур, одного працівника травмовано у результаті навмисної травми, заподіяної іншою особою та 2 - унаслідок інших видів подій

Основні причини настання нещасних випадків:

26 нещасних випадків, 3 яких 2 групові, сталися 3 організаційних причин, унаслідок яких травмовано 28 працівників, у тому числі 3 із смертельним наслідком; 3 нещасні випадки - 3 технічних причин, унаслідок яких травмовано 3 працівників; 5 нещасних випадків - 3 психофізіологічних причин.

Організаційні причини:

- невиконання вимог інструкцій 3 охорони праці (код класифікатора - «24.2») - травмовано 12 працівників, у тому числі 1 із смертельним наслідком;

- невиконання посадових обов'язків (код класифікатора - «24.1») - травмовано 6 працівників, у тому числі 1 із Смертельним наслідком;

- порушення технологічного процесу (код класифікатора - «18») - травмовано 3 працівників;

- порушення правил безпеки руху (код класифікатора - «21») - травмовано 2 працівників;

- залучення до роботи працівників не за спеціальністю (професією) (код класифікатора - «17») - трав- 
мовано 1 працівника;

-порушення трудової і виробничої дисципліни (код класифікатора - «24») - травмовано 1 працівника;

-інші (код класифікатора - «25») - травмовано 3 працівників, у тому числі 1 із смертельним наслідком.

Технічні причини:

- відсутність проектної документації на будівництво виробничих об'єктів, споруд, обладнання, устаткування тощо (код класифікатора - «03») травмовано 1 працівника;

- незадовільний технічний стан засобів виробництва (код класифікатора «06.2») - травмовано 1 працівника;

- незадовільний технічний стан транспортних засобів (код класифікатора - «06.3») - травмовано 1 працівника.

Психофізіологічні причини:

особиста необережність потерпілого (код класифікатора - «32») - травмовано 3 працівників;

незадовільні фізичні дані або стан здоров'я (код класифікатора - «29») - травмовано 1 працівника;

травмування внаслідок протиправних дій інших осіб (код класифікатора - «31») - травмовано 1 працівника.

На підставі проведеного аналізу ми побачили, що найчастіше нещасні випадки були пов'язані 3 невиконанням інструкцій 3 охорони праці, порушенням вимог безпечного виконання робіт, правил безпеки дорожнього руху, недооцінкою небезпеки, нехтуванням вимог безпечного виконання робіт підвищеної небезпеки.

Аналіз основних статистичних показників травматизму, представлених у табл. 1 вказує на погіршення безпеки праці у нафтогазовій галузі у порівнянні з 2017 роком, що говорить про неефективність заходів 3 покращення умов праці на підприємствах.

Таблиця 1 - Показники травматизму у нафтогазовій галузі

\begin{tabular}{|l|c|c|}
\hline \multicolumn{1}{|c|}{ Показник } & 2018 р. & 2017 p. \\
\hline Коефіцієнт частоти, $\mathrm{K}_{\mathrm{u}}$ & 0,519 & 0,486 \\
\hline Коефіцієнт тяжкості, $\mathrm{K}_{\mathrm{u}}$ & 76,6 & 71,0 \\
\hline $\begin{array}{l}\text { Кількість людино-днів } \\
\text { непрацездатності }\end{array}$ & 2529 & 2272 \\
\hline
\end{tabular}

Отже, питання створення належних, безпечних і здорових умов праці, запобігання нещасним випадкам на підприємствах у нафтогазовій галузі залишаються актуальними і потребують постійної посиленої уваги насамперед з боку керівництва підприємств та їх відповідних служб.

Одним із суттєвих недоліків діючих систем управління охороною паці (СУОП) у нафтогазовій галузі є відсутність системного підходу до аналізу усього комплексу потенційних небезпек на робочих місцях. Як правило СУОП побудовані за принципом дотримання вимог нормативно-правових актів 3 охорони праці без аналізу можливого виникнення загроз в процесі виробничої діяльності, особливо при експлуатації потенційно небезпечних об'єктів.
Згідно з вимогами OHSAS 18001 СУОП пропонується розробляти як систему управління гігієною $\mathrm{i}$ безпекою праці з метою надання організації можливості контролювати виробничі ризики і поліпшити свою діяльність. Це можливо за умови використання елементів ідентифікації небезпек, оцінки (прогнозу) можливих ризиків та управління ними.

Процес створення такої системи у нафтогазовій галузі розпочато зі створення методики ідентифікації небезпек та ідентифікації небезпек та оцінювання ризиків у сфері промислової безпеки для об'єктів газотранспортної системи [2]. На основі цієї методики розроблено стандарт СОУ 60.330019801081:2010 «Система управління промисловою безпекою. Ідентифікація небезпек та оцінювання ризиків. Методика». Використання вказаної методики дозволяє визначати потенційні небезпеки на робочих місцях підприємств нафтогазової галузі та проводити оцінку можливих ризиків.

Ідентифікація небезпек на робочих місцях здійснюється в результаті:

- аналізу нормативно-правових актів 3 охорони праці;

- інструкцій з охорони праці та пожежної безпеки;

- інструкції з експлуатації машин і механізмів та ін.;

- результатів розслідування аварій, професійних захворювань та нещасних випадків на виробництві;

- результатів перевірки підприємства органами державного нагляду 3 питань охорони та гігієни праці, пожежної безпеки»

- атестації робочих місць.

Для вирішення завдання оптимізації управління ризиками пропонується алгоритм, представлений на рис. 1.

Відповідно до рис. 1. На першому етапі проводиться збір інформації про небезпечні та шкідливі фактори, стан машин та механізми на кожному робочому місці, встановлюються відповідно до чинного законодавства вимоги (нормативні показники щодо безпечного ведення робіт), порушення яких спричинює ризик виникнення аварійної ситуації, нещасних випадків та професійних захворювань.

На етапі 2 на основі накопиченої на першому етапі інформації проводиться ідентифікація небезпек та створюється реєстр небезпек. Крім того, визначаються об'єкти, на яких можуть бути запропоновані заходи $з$ підвищення безпеки праці.

На етапі 3 для кожного виробничого об'єкту проводиться оцінка потенційних ризиків. Відповідно до [1].Формула оцінки R - ризику небажаної ситуації має вигляд

$$
\mathrm{R}=\mathrm{P} \cdot \mathrm{E} \cdot \mathrm{S}
$$

де $\mathrm{P}$ - ймовірність існування ризику виникнення небезпечної ситуації; Е - частота виникнення небезпеки; $\mathrm{S}$ - серйозність небажаних наслідків. 


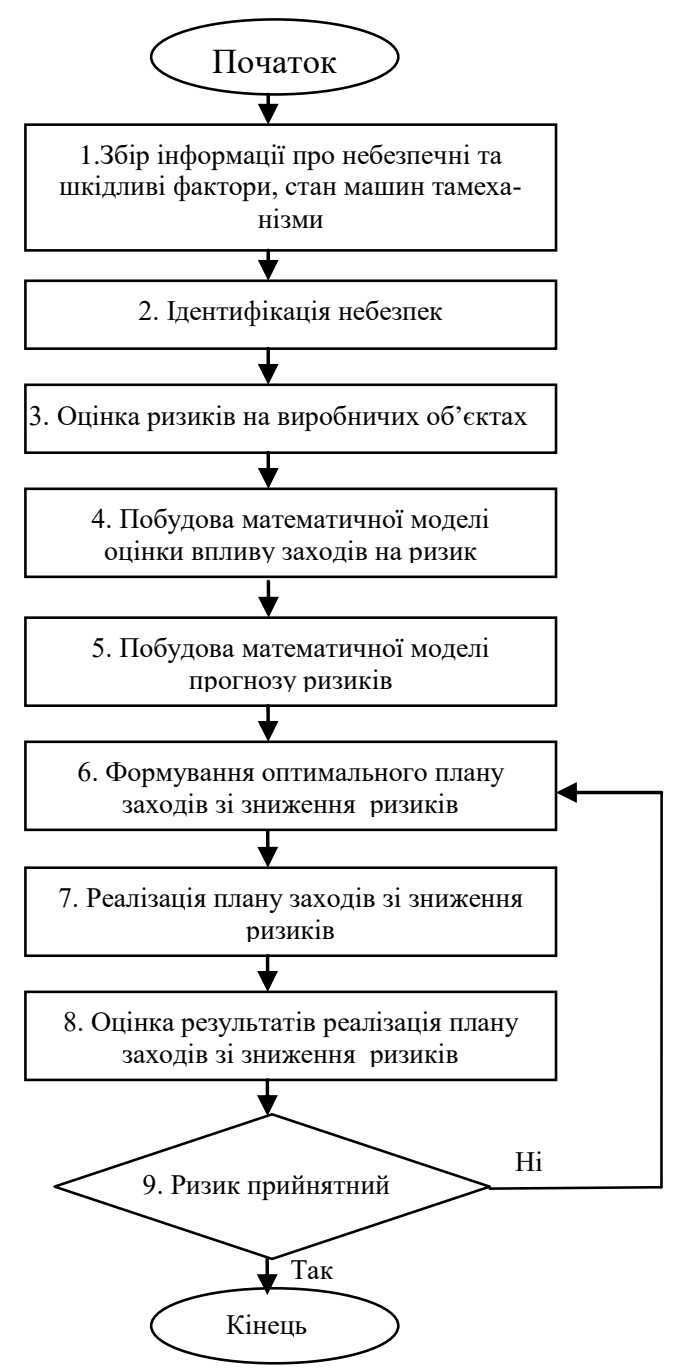

Рисунок 1 - Алгоритм оптимізації управління ризиками

На етапі 4 визначаються математичні моделі для розрахунку ризиків виникнення небезпечних ситуацій з врахуванням впливу на нього заходів з підвищення безпеки виробництва.

У формалізованому вигляді зв'язок ризику виникнення небезпечних ситуацій із заходами профілактичного (попереджувального) характеру, можна зобразити у вигляді

$$
\mathrm{R}_{\mathrm{s}}=\mathrm{R}_{\mathrm{m}}+\sum \mathrm{f}_{\mathrm{i}}\left(\mathrm{Z}_{\mathrm{i}}\right)
$$

де $\mathrm{R}_{\mathrm{s}}$ - ризик виникнення небезпечної ситуації; $\mathrm{R}_{\mathrm{m}}$ некерований ризик виникнення небезпечної ситуації; $\mathrm{f}_{\mathrm{i}}\left(\mathrm{Z}_{\mathrm{i}}\right)$ - функція впливу $\mathrm{i}$ - го заходу профілактичного (попереджувального) характеру $\mathrm{Z}_{\mathrm{i}}$ на ризик.

Для окремого профілактичного заходу залежність (3) можна трансформувати за двома варіантами.

Перший, - коли визначається вплив на загальний ризик цього заходу

$$
\mathrm{R}_{\mathrm{s}}=\mathrm{R}_{0}+\mathrm{f}_{\mathrm{i}}\left(\mathrm{Z}_{\mathrm{i}}\right)
$$

де $\mathrm{R}_{0}-$ ризикдо впровадження заходу; $\mathrm{f}_{\mathrm{i}}\left(\mathrm{Z}_{\mathrm{i}}\right)$ - функція впливу i-го заходу профілактичного (попереджувального) характеру $\mathrm{Z}_{\mathrm{i}} \mathrm{Ha}$ ризик виникнення небезпечної ситуації.

Другий варіант - це визначення впливу на ризик виникнення небезпечної ситуації, зумовлений конкретною виробничою небезпекою, тобто

$$
R_{j}=R_{0_{j}}+f_{j}\left(Z_{j}\right)
$$

де $\mathrm{R}_{\mathrm{j}}$ - ризик виникнення небезпечної ситуації від jтої виробничої небезпеки після запровадження $i$-го профілактичного заходу; $\mathrm{R}_{0_{\mathrm{j}}}-$ ризик виникнення небезпечної ситуації до запровадження i-того профілактичного заходу; $\mathrm{f}_{\mathrm{i}}\left(\mathrm{Z}_{\mathrm{i}}\right)$ - функція впливу i-го заходу профілактичного (попереджувального) характеру $\mathrm{Z}_{\mathrm{i}}$ на ризик виникнення небезпечної ситуації.

На етапі 5 здійснюється побудова математичних моделей прогнозу значень ризику в результаті реалізації заходів профілактичного характеру. Для цього визначаються матриці $\mathrm{A}_{0}-$ матриця врахування некерованої зміни ризику та $\mathrm{A}_{1}$ - матриця коефіцієнтів впливу заходів на ризик. Математична модель прогнозу матиме вигляд

$$
\left.\begin{array}{c}
R(t+1)=R(t)+A_{1} R(t)+A_{2} Z(t) \\
t=0, \ldots, N-1 ; \quad R(0)=r ; \\
Z(t) \geq 0 ; \quad t=0,1, \ldots, N-1 ; \\
R(t) \geq 0 .
\end{array}\right\}
$$

де $\mathrm{N}$ - кількість точок прогнозу; $\mathrm{r}$ - початкове значення ризику; Z(t) - керуючі впливи заходів профілактичного характеру на ризик.

Записавши вираз (5) в диференціальній формі, отримаємо математичну модель зміни ризику виникнення небезпечної ситуації з урахуванням впливу профілактичних заходів

$$
\left.\begin{array}{c}
\frac{\mathrm{dR}}{\mathrm{dt}}=\mathrm{A}_{1} \mathrm{R}(\mathrm{t})+\mathrm{A}_{2} \mathrm{Z}(\mathrm{t}) ; \\
0 \leq \mathrm{t} \leq \mathrm{T} ; \\
\mathrm{R}(0)=\mathrm{r} ; \\
\mathrm{Z}(\mathrm{t}) \geq 0 ; \quad 0 \leq \mathrm{t} \leq \mathrm{T} ; \\
\mathrm{B} \cdot \mathrm{z}(\mathrm{t}) \leq \mathrm{C}
\end{array}\right\},
$$

де В - розмір витрат на реалізацію профілактичних заходів; C - максимально допустимі витрати на профілактичні заходи

На етапі 6 визначається такий план заходів Z(t), 0 $\leq \mathrm{t} \leq \mathrm{T}$, щоб отримати максимум функціоналу(7) при виконанні умов (6).

$$
\mathrm{L}=\sum_{\mathrm{i}=1}^{\mathrm{n}} \mathrm{R}_{\mathrm{i}}(\mathrm{t})
$$

На етапах 6-7 проводиться реалізація запропонованих заходів на виробничих об'єктах 3 подальшою оцінкою результатів зміни величини ризиків. Якщо оцінка величини ризиків не $є$ прийнятною то необхідно перейти на етап 6 та повторити процедуру вибору оптимального плану заходів. 
ВИСНОВКИ. Запропонована методологія дозволяє оцінювати ефективність плану заходів підвищення безпеки виробництва 3 урахуванням причинно-наслідкових зв'язків між реалізацією превентивних заходів та величиною ризику виникнення небезпечних ситуаційна виробництві.

Оцінки, отримані за допомогою методів прогнозування величини ризику виникнення небезпечних ситуацій та аналізу заходів зі зниження рівня травматизму та професійної захворюваності, $\epsilon$ лише базою для прийняття остаточного рішення з управління охороною праці підприємства. Крім цього можуть братися до уваги додаткові критерії, у тому числі й неформального характеру. Запропонований підхід дозволяє перейти до наступного етапу - створення автоматизованої системи управління охороною праці на підприємствах нафтогазової промисловості, в основу якої покладено науково обгрунтовані методи оцінки ефективності профілактичних заходів зі зниження рівня виробничого травматизму та професійної захворюваності.

\section{ЛІТЕРАТУРА}

1. Рекомендації щодо розроблення системи профілактики виробничого травматизму (СПВТ) на основі ризикоорієнтованого підходу. Охорона праці. На допомогу спеціалісту з охорони праці. К., 2012. № 12. C. 37-51.

2. A. P. Bochkovskyi, N. Yu. Sapozhnikova, V. D. Gogunskii Legal and organizational issues of improving the labor protection and industrial safety level at Ukrainian enterprises. Naukovyi Visnyk Natsionalnoho Hirnychoho Universytetu. 2017. Vol. 5 (161). P. 100-108.

3. Кружилко О. Є., Сторож Я. Б., Гуць В. С., Полукаров Ю. О., Землянська О. В. Прогнозування професійної захворюваності зварників залежно ві- думов праці. Вісник Кременчуиьького національного університету імені Михайла Остроградського. 2017. Вип. 6/2017 (107). Частина 1. С. 129-135.

4. Лисяний Г. М. Охорона праці в нафтогазовій галузі. / за редакцією Г.М. Лисяного. ІваноФранківськ: Симфонія форте, 2-15. - 304 с.

5. Khan F., Rathnayaka S., Ahmed S. Methods and models in process safety and risk management: Past, present and future. Process Safety and Environmental Protection. 2015. Vol. 98. Pp. 116-147. DOI: 10.1016/j. psep. 2015.07.005

6. Storozh Ya., Kruzhilko O., Maystrenko V., Polukarov O. (2018), Information and analytical support improvement for production risk assessment in mining and processing industry, Resources and resource-saving technologies in mineral mining and processing, Multiauthored monograph. UNIVERSITAS Publishing, 363p.

7. Ткачук К. Н., Кружилко О. Є. Прогнозування виробничого травматизму: монографія. Київ: Основа, 2014. 345 с.

8. Бочковський А. П., Сапожнікова Н. Ю. Науково - практичні аспекти мінімізації ризиків виникнення професійних небезпек. Екологічна безпека та збалансоване ресурсокористування. 2017. № 2(16). C. 92-101.

9. Лактіонов С. О., Сєріков Я. О. Виробничий травматизм і професійна захворюваність як проблема сучасності: аспекти, причини, шляхи запобігання. Міжнародна конференція: Безпека людини у сучасних умовах. НТУ «ХПІ», 2015. С. 219-224.

10. Jain P., Pasman H. J., Waldram S., Pistikopoulos E. N., Mannan M. S. Process Resilience Analysis Framework (PRAF): A systems approach for improved risk and safety management. Journal of Loss Prevention in the Process Industries. 2018. Vol. 53. Pp. 61-73. DOI: 10.1016/j.jlp.2017.08.006

\section{OPTIMIZATION OF RISK MANAGEMENT AT THE ENTERPRISE OF OIL AND GAS INDUSTRY}

\section{Yu. Lakh}

Public Agency "National Scientific Research Institute of Industrial Protection and Occupational Safety"

vul. Vavilovykh, 13, Kyiv, 04060, Ukraine. E-mail: ndiop@ndiop.kiev.ua

Purpose. The present study focuses on increasement of labor protection management effectiveness through the use of methods of mathematical modeling and optimization of planning measures to reduce the hazardrisks, occupational injuries and occupational disease. Methodology. Labor protection systems at the current level of their development are increasingly using a risk-oriented approach in decision making, therefore, to improve the production safety, a new method was proposed for assessing the effectiveness of measures to reduce the hazardrisks, occupational injuries and occupational diseases at oil and gas industry enterprises, taking into account causality between preventive measures implementation and risk magnitude. Results. The paper analyzes state of industrial injuries and theiroccurrencereasons and main statistical indicators in the oil and gas industry for 2017-2018. Weanalyze events that have resulted in injured workers. Bases on the analysis we found the most frequent accidents were related to non-compliance with labor safety instructions, violations of safe work requirements, traffic safety rules, underestimation of danger, and neglect of the requirements for the high-risk worksafe execution. We developed the mathematical model for predicting the magnitude of the risk of occurrence of hazardous situations at the enterprise objects according to the results of the analysis of occupational injury conditions and hazardidentifications. The research presents the algorithm for choosing the optimal plan of preventive measures for reducing the hazard magnitude. Main difference from current algorithms is the use of mathematical model of risk change forecasting trends, that allows to evaluate peculiarities of individual measureinfluences. Practical value. The obtained result allows to increase the effectiveness of measureplanning on labor protection and safety of production, taking into account impact on the risk of hazardoccurrence in the production. Conclusions. The proposed approach allows us to proceed to the next stage - the creation of an automated control system for oil and gas industry enterprises.

Key words: occupational injuries, occupational diseases, risk, prognostic model. 


\section{REFERENCES}

1. Recommendations on the development of a system for the prevention of occupational injuries (SPOI) based on a risk-oriented approach. Occupational Health. To help the occupational safety specialist, 2012, no. 12 , pp. 37-51.

2. Bochkovskyi, A. P., Sapozhnikova, N. Yu., Gogunskii, V. D. (2017), Legal and organizational issues of improving the labor protection and industrial safety level at Ukrainian enterprises, Naukovyi Visnyk Natsionalnoho Hirnychoho Universytetu, no. 5 (161), pp. 100-108.

3. Kruzhilko, O. E., Storozh, Ya. B., Guts, V. S., Polukarov, Y. O., Zemlyans'ka, O. V. (2017), Prediction of occupational morbidity of welders depending on the working conditions, Transactions of Kremenchuk Mykhailo Ostrohradskyi National University, Vol. 107, part 1, pp. 129-135.

4. Lisaniy, G. M. (2015), Labor protection in the oil and gas industry. Simfoniya forte, P. 304.

5. Khan, F., Rathnayaka, S., Ahmed, S. (2015), Methods and models in process safety and risk management: Past, present and future, Process Safety and Environmental Protection, Vol. 98, pp. 116-147, DOI: 10.1016/j.psep.2015.07.005

4.
6. Storozh, Ya., Kruzhilko, O., Maystrenko, V., Polukarov, O. (2018), Information and analytical support improvement for production risk assessment in mining and processing industry, Resources and resource-saving technologies in mineral mining and processing, Multi-authored monograph. UNIVERSITAS Publishing, $363 \mathrm{p}$.

7. Tkachuk, K. N., Kruzhilko, O. E. (2014), Forecasting of occupational injuries: monograph, Osnova, $345 \mathrm{p}$.

8. Bochkovsky, A. P., Sapozhnikova, N. Yu. (2017), Scientific - practical aspects of minimizing the risks of professional dangers, Ecological safety and balanced resource use, Vol. 2 (16), pp. 92-101.

9. Laktionov, S. O., Serikov, Ya. O. (2015), Industrial injuries and occupational morbidity as a problem of the present: aspects, causes, ways of prevention, International conference: Human security in modern conditions. NTU "KhPI", pp. 219-224.

10. Jain, P., Pasman, H. J., Waldram, S., Pistikopoulos, E. N., Mannan, M. S. (2018), Process Resilience Analysis Framework (PRAF): A systems approach for improved risk and safety management, Journal of Loss Prevention in the Process Industries, Vol. 53. pp. 61-73. DOI: 10.1016/j.jlp.2017.08.006 